\title{
KETERLIBATAN LANSIA DALAM PENGAJIAN: MANFAAT SPIRITUAL, SOSIAL, DAN PSIKOLOGIS
}

\author{
Santi Sulandari ${ }^{1 \cdot} \cdot$ Mei Wijayanti ${ }^{2} \cdot$ Ria Dessy Pornama Sari ${ }^{3 .}$ \\ Universitas Muhammadiyah Surakarta \\ ss280@ums.ac.id
}

\begin{abstract}
The increase in the number of older people over the years lead to consequences that need to address, including the psychological well-being issues. Religious activities is one of the alternatives to prevent these problems. One of the religious activities that is participated frequently by Muslim in Indonesia, particularly in Solo, is pengajian. This research objective was to describe the benefits of older people's involvement in pengajian. The characteristics of the informans were individuals aged 60 years or older, engange to pengajian, and live in Solo. The data was collected using semi-structured interview. The results showed that the activities that were done on pengajian were listening to religious speech; reading Al-Qur'an (tadarus); learning As-Sunnah; learning tajweed; learning and discussing tafsir (the message on Qur'an); inviting and donating to orphans; and praying (dua). Older people who participated in pengajian did not only obtain spiritual benefit (having new religious knowledges) but also gained social benefits (maintaining good relationships wtih others, having more friends, and sharing the knowledge), as well as, received psychological benefits (being pleased). This study also emphasized that, for some informants, spiritual and social benefits also could lead to psychological benefits.
\end{abstract}

Keyword: activity, benefits, recitation of the Quran, religious

Abstrak. Peningkatan jumlah lansia dari tahun ke tahun menimbulkan konsekuensikonsekuensi yang harus dihadapi termasuk didalamnya masalah kesejahteraan psikologis. Aktivitas keagamaan adalah salah satu alternatif untuk mencegah masalah-masalah tersebut. Salah satu aktivitas keagaman yang sering dilakukan masyarakat Muslim di Indonesia, khususnya di Solo adalah pengajian. Penilitian ini bertujuan untuk memaparkan manfaat-manfaat yang diperoleh lansia dengan mengikuti pengajian. Adapun kriteria informan penelitian ini adalah individu yang berusia 60 tahun keatas, mengikuti pengajian, dan tinggal di Solo.Metode pengumpulan data menggunakan wawancara semi terstruktur. Hasil penelitian ini menunjukkan bahwa kegiatan yang dilakukan pada saat pengajian meliputi: mendengarkan ceramah agama; bertadarus; kajian As-Sunnah; belajar tajwid; kajian tafsir; mengundang dan menyantuni anak yatim; dan membaca doa-doa. Lansia yang mengikuti pengajian tidak hanya mendapatkan manfaat spiritual (mendapatkan ilmu baru terkait pengetahuan agama) tetapi juga manfaat sosial (mempererat tali silahturami, menambah pertemanan, dan berbagi pengetahuan) serta manfaat psikologis (perasaan senang). Penelitian ini juga menekankan bahwa, pada beberapa informan, manfaat spiritual dan sosial juga dapat berujung pada manfaat psikologis.

Kata kunci: aktivitas, keagamaan, manfaat, pengajian 


\section{PENDAHULUAN}

Fase lanjut usia (lansia) merupakan tahap penutup dalam perkembangan manusia setelah seseorang berada pada masa dewasa akhir. Mereka telah mengalami berbagai proses perkembangan dan peningkatan kemampuan sejak mereka lahir hingga mencapai masa dewasa akhir. Lansia cenderung memiliki ketrampilan emosional yang baik; optimis dalam memandang kehidupan; bijaksana dalam menentukan pilihan; sabar dalam menghadapi permasalahan; dan merasa nyaman dengan dirinya sendiri dan lingkungan (Bryner, 2010; Santrock, 2004). Namun di sisi lain Suhartini (2014) mengemukakan bahwa perkembangan di fase lansia juga ditandai dengan adanya perubahan pada kondisi fisik seperti bagian wajah, tangan, kulit, dan panca indera; bagian dalam tubuh; dan fungsi motorik (kekuatan, kecepatan dan belajar keterampilan baru).

Berdasarkan hasil survey dari Badan Pusat Statistik [BPS] (2013) jumlah populasi lansia di Indonesia mengalami peningkatan di setiap tahunnya. Data pada tahun 2010 jumlah lansia sekitar $7,56 \%$ dari jumlah penduduk Indonesia dan pada tahun 2015 meningkat menjadi 8,49\%. Populasi lansia diprediksi akan terus meningkat di tahun-tahun berikutnya. Berdasarkan survey tersebut telah diproyeksi populasi lansia pada tahun 2020 sebesar 9,99\%, pada tahun 2025 meningkat menjadi $11,83 \%$ dan terus meningkat hingga $13,82 \%$ pada tahun 2030

Gambar 1. Peningkatan Populasi Lansia di Indonesia Tahun 2010-2030

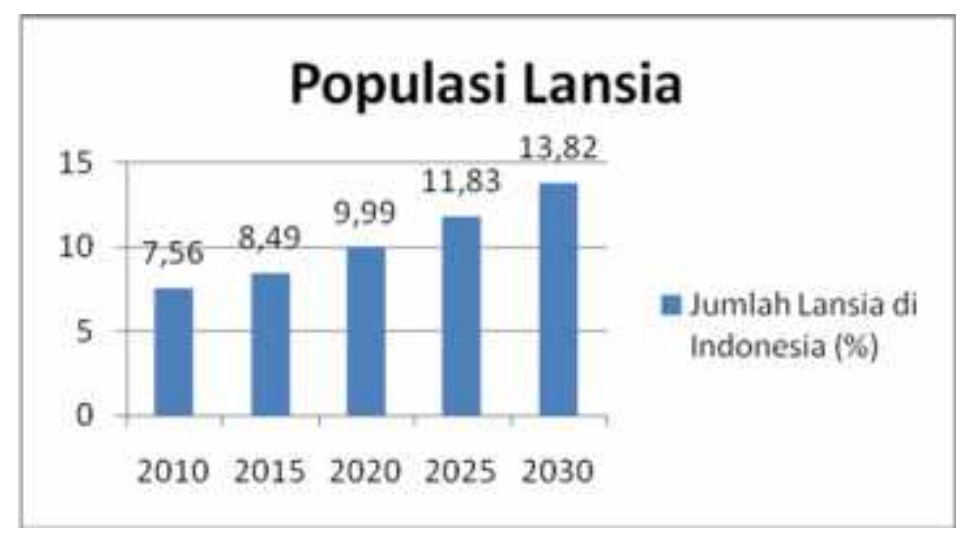

Peningkatan populasi lansia merupakan sesuatu yang layak untuk dibanggakan karena mampu menunjukkan peningkatan UHH (Usia Harapan Hidup) di Indonesia. Namun demikian, berbagai permasalahan muncul terkait dengan kesejahteraan lanjut usia. Suardiman (2011) mengungkapkan berbagai permasalahan yang timbul di masa lansia antara lain: (1) masalah ekonomi yang ditandai dengan menurunnya produktivitas kerja, memasuki masa pensiun, dan berhenti dari pekerjaan, (2) masalah sosial yang ditandai dengan berkurangnya kontak sosial baik dengan keluarga, masyarakat, maupun teman kerja, (3) masalah kesehatan yang ditandai dengan kerentanan terhadap berbagai penyakit, (4) masalah psikologis yang ditandai dengan perasaan tidak percaya diri, kesepian, terasing dari lingkungan, post power syndrome, ketidakberdayaan, ketidakbergunaan, dan ketidakbahagiaan. Lansia memiliki kapasitas yang kurang baik untuk beraktifitas secara optimal karena mereka cenderung depresi dalam menghadapi berbagai permasalahan di 
masa akhir kehidupannya (Laksmana, 2013; Suardiman, 2011). Di Indonesia, persentase lansia yang mengalami stres menunjukkan angka $12,7 \%$ dari populasi lansia (Kementerian Kesehatan Republik Indonesia [Kemenkes RI], 2012).

Lansia memiliki kerentanan terhadap ketenangan dan kebahagiaan hidupnya. Seiring betambahnya usia, maka akan semakin bertambah pula kecenderungan perasaan negatif untuk muncul (Candra, 2012; Rafikasari, 2015). Terdapat berbagai cara yang dapat dilakukan oleh lansia untuk memperoleh kebahagiaan tersebut. Salah satunya adalah dengan meningkatkan religiusitas. Hakim (2003) menjelaskan bahwa perhatian seseorang akan keagamaan akan semakin meningkat sejalan dengan bertambahnya usia. Hakim menambahkan walaupun secara fisik seorang lansia mengalami penurunan, tetapi dalam melakukan aktivitas agama justru mengalami peningkatan. $\mathrm{Ai}$ and Branco (dalam Sulandari, 2014) menyatakan bahwa keagamaan merupakan bagian yang penting bagi seorang lansia. Sulandari (2014) juga menekankan bahwa lansia yang merasa lebih dekat dengan Tuhannya, maka ia akan cenderung merasa lebih bahagia dalam keadaan apapun yang sedang dialaminya.

Bentuk dari keberagamaan, salah satunya dapat diwujudkan melalui aktivitas keagamaan. Hasil penelitian yang dilakukan oleh Francis, Yablon, dan Robbins (2014) memperkuat penjelasan bahwa orang yang aktif dengan aktivitas keagamaan akan merasa lebih bahagia daripada orang yang pasif dalam aktivitas keagamaan. Melalui aktivitas keagamaan, lansia akan memperoleh kehidupan yang lebih baik (kebahagiaan). Kebahagiaan hidup yang dirasakan oleh lansia akan terus terjaga apabila lansia sendiri juga menjaga aktivitas keagamaannya. Fauzi (2012) mengartikan aktivitas keagamaan sebagai suatu rancangan atau susunan kegiatan yang bersifat keagamaan, berlangsung secara berkesinambungan di dalam sebuah organisasi yang bertujuan untuk menghasilkan pengalaman terhadap suatu ajaran agama. Lebih lanjut, Maisyaroh (2009) mendefinisikan aktivitas keagamaan sebagai suatu bentuk usaha yang dilaksanakan untuk mewujudkan atau mengaplikasikan iman ke dalam perilaku keagamaan. Menurut Suardiman (2011), terdapat berbagai bentuk-bentuk aktivitas keagamaan yang dapat dilakukan oleh seseorang, seperti: shalat 5 waktu dan shalat yang lain, berpuasa, kegiatan yang berorientasi pada zakat, ibadah Haji, mengikuti atau mengadakan kegiatan pengajian, melaksanakan anjuran dan menghindari larangan oleh masing-masing ajaran agama yang dianut, membaca buku-buku keagamaan, mengikuti acara radio/TV tentang agama, membantu anak yatim piatu, dan mendalami isi Al-Qur'an dan lain sebagainya.

Pengajian merupakan salah satu bentuk dari aktivitas keagamaan yang dilakukan umat Muslim. Aktivitas ini bukan merupakan hal yang wajib untuk diikuti tetapi kegiatan seperti ini banyak diminati oleh masyarakat. Istilah "pengajian" berasal dari kata kerja "mengaji" yang berarti mempelajari ilmu agama dari seseorang yang dianggap ahli dalam hal agama. Selain itu juga diartikan sebagai kegiatan atau kesibukan tentang pengajaran agama islam, yang mana pengajaran tersebut berupa acara tabligh atau juga pembacaan Al Qur'an (Alfisyah, 2009). Kegiatan pengajian sering diisi dengan mendengarkan ceramah, siraman rohani, belajar lebih dalam tentang AsSunnah, dan Tadarus. Millie (dalam Shoim \& Mudzakkir, 2013) menambahkan bahwa kegiatan pengajian dapat disajikan dalam beberapa bentuk, diantaranya: tablig 
akbar, dakwah, malam tausiyah, dan malam diskusi.

Hal ini juga sesuai dengan hasil data awal yang diperoleh melalui wawancara dengan ibu SHS. SHS menyampaikan bahwa pengajian yang diikutinya diisi dengan kegiatan, seperti: tadarus, mendengarkan ceramah, kajian tafsir, As-Sunnah, dan belajar tajwid. Manfaat yang diperoleh lansia dalam mengikuti pengajian adalah mendapatkan ilmu baru. Hal tersebut membuat lansia berusaha menjadi lebih baik dengan menerapkan ilmu yang diperoleh di kehidupan sehari-hari. Terkait dengan manfaat yang diperoleh oleh lansia tersebut dalam mengikuti pengajian mampu membuat lansia untuk merasa bahagia. Penelitian tentang pengajian terkait dengan psikoreligius juga telah dilakukan oleh Handayani (2011). Musfirotun (2013) juga melakukan penelitian terkait pengajian dan manfaat sosialnya. Namun, penelitian tersebut lebih bersifat kuantitatif dan kurang mendiskripsikan manfaatmanfaat pengajian dan juga tidak secara khusus ditujukan kepada lansia.

Oleh karena itu, penelitian ini bertujuan mendeskripsikan secara lebih mendalam mengenai manfaat yang diperoleh lansia dalam mengikuti pengajian. Hasil penelitian ini diharapkan dapat menjadi acuan untuk tokoh agama, praktisi, dan peneliti terkait dengan pentingnya atau besarnya manfaat yang diperoleh dari kegiatan pengajian bagi lansia. Berdasarkan hal tersebut maka peneliti mengajkan pertanyaan penelitian "apa saja manfaat-manfaat yang diperoleh lansia dari keikutsertaan dalam kegiatan pengajian?"

\section{METODE}

Penelitian ini menggunakan pendekatan kualitatif fenomenologi, yaitu metode yang digunakan untuk memahami dan mendiskripsikan makna-makna dari pengalaman hidup seseorang sesuai dengan fenomena yang sedang diteliti. Fenomena yang dimaksud terkait dengan manfaatmanfaat yang diperoleh lansia melalui keterlibatannya dalam pengajian.

Deskripsi Fenomena

Pengajian merupakan salah satu bentuk dari aktivitas keagamaan yang diikuti oleh masyarakat Muslim di Solo. Meskipun kegiatan ini tidak wajib untuk diikuti, namun lansia Muslim di Solo memiliki antusias untuk mengikutinya. Hal-hal yang dilakukan di dalam pengajian dapat berupa: mendengarkan ceramah, bertadarus, belajar tajwid, belajar tafsir Al-Qur'an dan Hadist. Kegiatan ini tidak hanya memberikan manfaat secara keilmuan (menambah ilmu agama) tetapi juga memberikan kesempatan kepada lansia untuk dapat menjalin hubungan sosial.

\section{Informan Penelitian}

Pemilihan informan dalam
penelitian ini
menggunakan purposive sampling yaitu pemilihan informan dengan menggunakan ciri-ciri ataupun kriteria yang telah ditentukan sebelumnya. Ciri-ciri informan dalam penelitian ini antara lain: lansia yang berusia 60 tahun keatas, terlibat dalam aktivitas keagamaan yang berupa pengajian, berdomilisi di Solo.

Metode Pengumpulan dan Anallsis Data

Pengumpulan data dalam penelitian ini menggunakan metode wawancara. Wawancara dilakukan secara semi terstruktur berdasarkan panduan wawancara yang telah dibuat sesuai dengan tema yang akan diungkap. Pada pelaksanaan pengumpulan data, muncul pertanyaan-pertanyaan lanjutan diluar panduan wawancara. Pertanyaan tambahan tersebut menyesuaikan 
dengan respon atau jawaban yang diberikan oleh informan.

Data penelitian ini dianalisis menggunakan program QSR Nvivo11 yang dapat membantu dalam proses peng-coding-an, pengolahan dan pengkategorisasian pengetahuan dianggap penting bagi peneliti (QSR Internasional, 2016). Alasan peneliti menggunakan perangkat ini karena perangkat ini dapat menyimpan data dan menempatkan kualitatif secara efisien. Melalui program QSR NVivo11, peneliti dapat mengelompokkan hasil penelitian dalam beberapa poin dengan cara membuat nodes dan sub-nodes. Nodes berfungsi sebagai poin utama yang akan dibahas oleh peneliti, sedangkan sub-nodes berfungsi sebagai rincian dari nodes yang telah dibuat sebelumnya. Nodes yang dibuat di dalam program QSR NVivo11 mengacu pada pokok pertanyaan yang ada di dalam panduan wawancara.

\section{HASIL DAN PEMBAHASAN}

Berdasarkan penelitian yang telah dilakukan maka diperoleh hasil yang meliputi: profil informan dan kegiatan pengajian yang dilakukan; dan manfaat-manfaat yang diperoleh lansia dalam mengikuti pengajian.

Profil Informan dan Kegiatan

Pengajian yang

Dilakukan

Profil informan meliputi: jenis kelamin, usia, dan pekerjaan. Informan yang terlibat dalam penelitian ini adalah empat lansia perempuan dan dua lansia laki-laki. Usia informan memiliki rentang 61 85 tahun. Tiga informan bekerja sebagai wirausaha dan tiga lainnya tidak bekerja. Adapun kelompok pengajian yang diikuti informan, antara lain: kelompok pengajian masjid, pengajian pensiunan, pengajian ibu-ibu, dan pengajian rombongan haji, pengajian desa. Kegiatan yang biasanya dilakukan dalam pengajian, meliputi: tadarus, mendengarkan ceramah, mengkaji tafsir Al-Qur'an, mengkaji AsSunnah, dan belajar tajwid, mengundang dan menyantuni anak yatim, burdah (membaca doa-doa). Kelompok pengajian dan kegiatan yang dilakukan saat pengajian pun bervariasi antara informan satu dengan yang lainnya, meskipun dibeberapa hal juga memiliki kesamaan. Lebih lanjut, profil informan dan kegiatan keagamaan yang dilakukan oleh informan dapat dilihat secara rinci di tabel 1.

Tabel 1. Profil informan dan kegiatan keagamaan

\begin{tabular}{|c|l|l|l|l|l|l|}
\hline $\begin{array}{l}\text { Info } \\
\mathbf{r}- \\
\text { man }\end{array}$ & $\begin{array}{l}\text { Usi } \\
\mathbf{a}\end{array}$ & $\begin{array}{l}\text { Jenis } \\
\text { kelami } \\
\mathbf{n}\end{array}$ & $\begin{array}{l}\text { Pekerja } \\
\text { an }\end{array}$ & $\begin{array}{l}\text { Kelomp } \\
\text { ok } \\
\text { pengajia } \\
\mathbf{n}\end{array}$ & Kegiatan & Waktu \\
\hline 1 & $\begin{array}{l}63 \\
\text { th }\end{array}$ & $\mathrm{P}$ & $\begin{array}{l}\text { Sudah } \\
\text { pensiun } \\
\text { / tidak } \\
\text { bekerja }\end{array}$ & Masjid & $\begin{array}{l}\text { Tadarus dan } \\
\text { mendengarkan } \\
\text { ceramah, Kajian } \\
\text { As-Sunnah, dan } \\
\text { tafsir }\end{array}$ & $\begin{array}{l}\text { Ada dua kelompok: } \\
\text { Seminggu sekali } \\
\text { dan sebulan sekali }\end{array}$ \\
\cline { 2 - 5 } & & & & & &
\end{tabular}




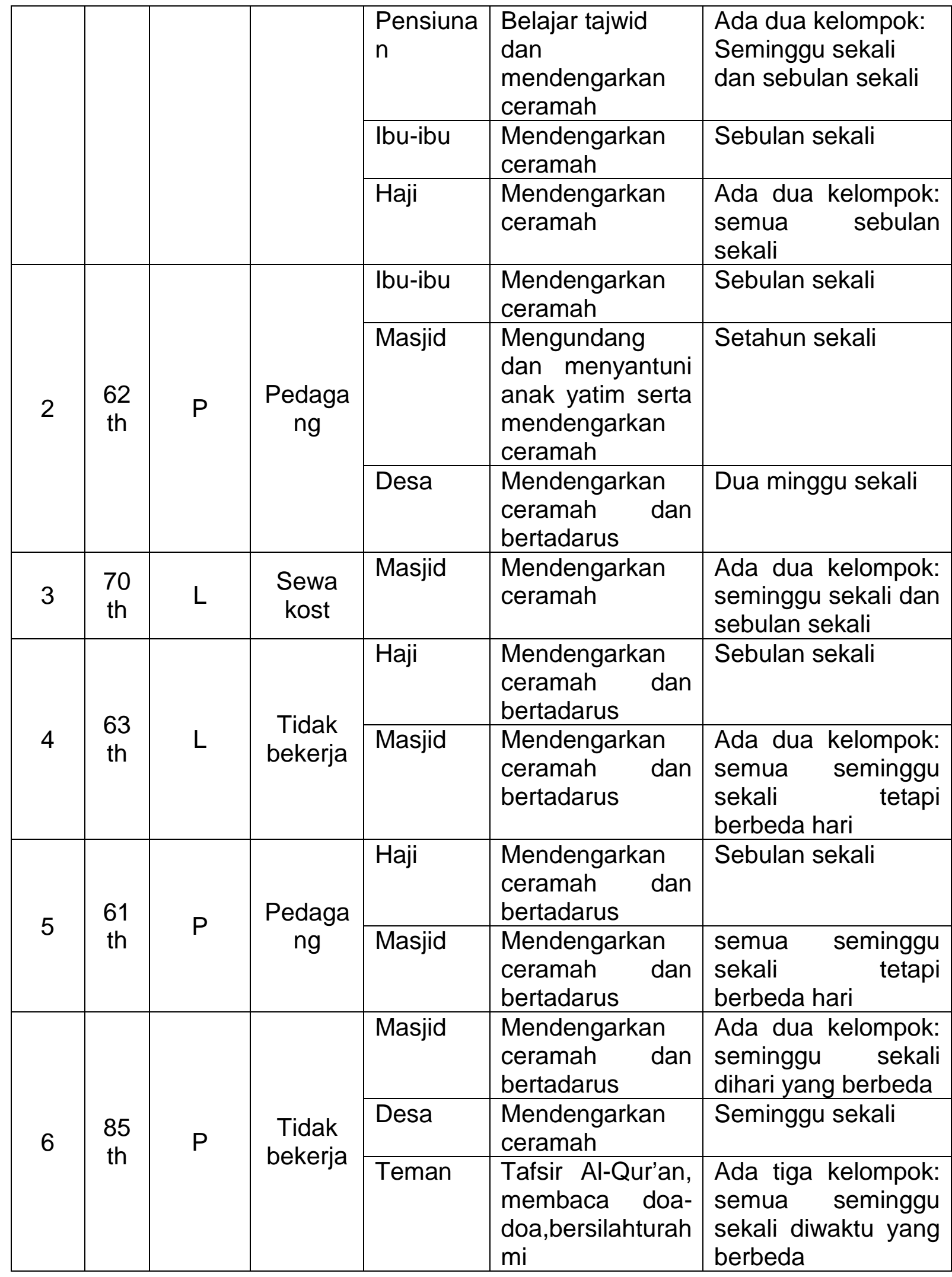


Manfaat Pengajian

Informan yang terlibat dalam penelitian ini mengaku bahwa dengan mengikuti pengajian, mereka mendapatkan berbagai manfaat yang meliputi: mendapatkan ilmu atau pengetahuan baru terkait agama; merasa senang; dapat mempererat tali silahturahmi; menambah teman baru;dan dapat berbagi pengetahuan.

a. Mendapatkan ilmu baru terkait pengetahuan agama

Seluruh informan menyatakan bahwa melalui kegiatan pengajian informan dapat memperoleh ilmu/pengetahuan baru terkait dengan keagamaan. Empat informan mengakui bahwa ternyata pengetahuan agama mereka masih kurang. Mengikuti pengajian mampu menambah pengetahuan mereka tentang agama sehingga lebih paham tentang ajaran agama Islam. Pengetahuan tersebut juga berguna sebagai panduan berperilaku secara tepat dalam kehidupan sehari-hari, seperti: cara mendidik anak, berbakti kepada orang tua, dan menjalin hubungan yang baik dengan tetangga. Hal tersebut diungkapkan oleh informan penelitian, seperti:

"Senang dan apa ya mbak ya dengan penjelasan-penjelasan yang diterangkan gurunya itu kok apa ya saya tu ternyata masih kurang sekali pengetahuan" . . . Pengen berperilaku lebih baik, perlu mengaplikasikan apa ya pada kehidupan sehari-hari gitu". [Informan 1]

"Carane ndidik anak, bekti karo moro tuwo, tonggo teparo" [mendapatkan ilmu baru]" . . . Soale lekas ajar sholat trus bareng-bareng berjanjen awan kae kan wis suwe, nak telu tahun we wis punjul nak berjanjen kan enek bulik tatik khan islam.e khusyuk ngandani hukume islam ngene-ngene kui”. [Informan 2]

"Dapat ilmu baru sering sering kita laksanakan." . . . Sebelum pengajian kan tidak melaksanakan setelah pengajian jadi melaksanakan”. [Informan 3]

"Ya untuk menambah ilmu pengetahuan, ya untuk pengetahuan yang tentang agama”. [Informan 4]

Lebih lanjut, informan lainnya juga menambahkan bahwa mengikuti pengajian dapat memperdalam pemahaman tentang isi Al-Quran serta hal-hal terkait kewajiban untuk sholat. Mereka mengaku:

"Trus menambah itu, menambah apa ilmu kita untuk isi Al-Qur'annya itu". [Informan 5]

"Kalo pengajian tahfid ya dapat ilmunya tahfid. Kalo pengajian biasa ya ada kayak sholat-sholat gitu kan jadi sekarang bisa menikmati bisa merasakan. Sekarang gitu, sejak udah tua ini". [Informan 6]

b. Mempererat tali silahturahmi Empat informan menyatakan bahwa pengajian, selain sebagai wadah untuk memperoleh ilmu pengetahuan mengenai agama, kegiatan tersebut juga memfasilitasi lansia untuk bersilaturahmi dengan temannya serta melakukan sesuatu hal bersama-sama seperti memahami terjemahan Al-Qur'an. Hal tersebut mampu mendekatkan hubungan pertemanan mereka dan menjaga sikap tenggang rasa.

"Saya yang jelas itu bisa ketemu silaturahmi gitu dengan teman-teman". [Informan 1] 
"Karo tonggo teparo iso apik". [Informan 2)

"Pisanan kumpul anu iku opo jenenge, silaturahmi, semua, sesama kelompok . . Kan itu mengartikan itu, dibaca bareng-bareng terus mengartikan, diterjemahkan bersama”. [Informan 5]

"kalau pengajian gitu ya keluar ketemu sama temen sama anak-anaknya gitu, jadi bisa ngobrol-ngobrol. Trus kalau ada yang sakit gitu dikasih pengumuman di masjid, trus nanti serombongan gitu jengukin barengbareng" (informan 6)

\section{c. Merasa senang}

Lima informan mengaku bahwa pengajian membuat informan merasa senang. Perasaan senang yang dirasakan setiap informan berbedabeda. Informan 2 menyampaikan bahwa dirinya merasa nyaman setelah mendengarkan ceramah agama dan merasakan kepuasan lahir dan batin. Informan 3 juga menambahkan bahwa mengikuti pengajian juga mampu menghilangkan kesedihannya karena lebih dapat menerima kondisi dirinya dan ketetapan Allah. Informan menyatakan:

"Nak bar mulih pengajian ngono kui umpomo bar ngrungok-ngrungokne ngno ki rasane kepenak ngno". [Informan 2]

"Ya dapat ketenangan, karena dapat ilmu kan kita tenang. Lewat ketenangan dapat ilmu baru gitu. Yang tadinya ndak tau jadi tau kan seneng, manfaatnya gitu. Bisa menghilangkan kesedihan. Kenapa harus sedih, kan Allah begini-begini gitu". [Informan 3]
“. . . [mendapatkan] Kepuasan lahir dan batin”. [informan 4]

Selanjutnya, informan 1, 5 dan 6 menekankan bahwa perasaan senang yang muncul juga dikarenakan adanya pengetahuan baru serta pendampingan dari ahli untuk memahami Al-Qur'an. Hal ini menunjukkan bahwa sebagian dari informan mendapatkan perasaan senang dari manfaat pengajian yang lain yaitu 'mendapatkan ilmu atau pengetahuan terkait agama'.

"Senang dan apa ya mbak ya dengan penjelasan-penjelasan yang diterangkan gurunya itu kok apa ya saya tu ternyata masih kurang sekali pengetahuan". [Informan 1]

"Nyemak Al-Qur'an kan saya kalo mbaca sendiri dengan artinya itu kan mengartikannya kurang. Lha ini kan ada ahlinya gitu lho, senengnya di situ". [Informan 5]

"Ya seneng dapat ilmu seneng ndengerke itu kan ilmu. seneng, kan dapat ilmu, dapat teman. Banyak lah faedahnya". [Informan 6]

Informan 5 menambahkan bahwa bertemu dengan teman lama dan menjaga hubungan mereka tetap harmonis mampu membuat mereka merasa senang. Manfaat pengajian yang berupa 'mempererat silahturahmi' ini ternyata juga terkait dengan manfaat lainnya 'merasa senang'.

“. . . Ben seneng [Ketika kumpul dengan teman] “. [Informan 5]

d. Menambah pertemanan 
Dua dari enam informan mengaku bahwa dengan mengikuti pengajian rutin membuat informan mendapatkan teman baru. Sering terlibat dalam aktivitas pengajian membuat informan bertemu dengan orang-orang baru sehingga dapat menambah teman. Hal ini diungkapkan oleh informan 5 dan informan 6, seperti:

"Kerep pengajian kui yo, tambah konco banyak [bertemu ditempat pengajian]". [Informan 5]

“. . . [mengikuti pengajian] Dapat teman [baru]". [Informan 6] e. Berbagi pengetahuan

Dua dari enam informan menyatakan bahwa manfaat yang dapat diperoleh dari pengajian adalah dapat menyalurkan ilmu atau sharing kepada orang lain yang belum mengetahuinya. hal tersebut diungkapkan oleh informan, antara lain:

"Dapat ilmu baru sering sering kita laksanakan soalnya kan pulang dari pengajian gitu di rumah terus saya cerita sama istri dari pengajian saya dapet ilmu kayak gini saya sampaikan ke istri". [Informan 3]

"Kita dapat ilmu, kita berikan pada orang lain yang belum tau." [Informan 4]

Gambar 2. Manfaat Pengajian

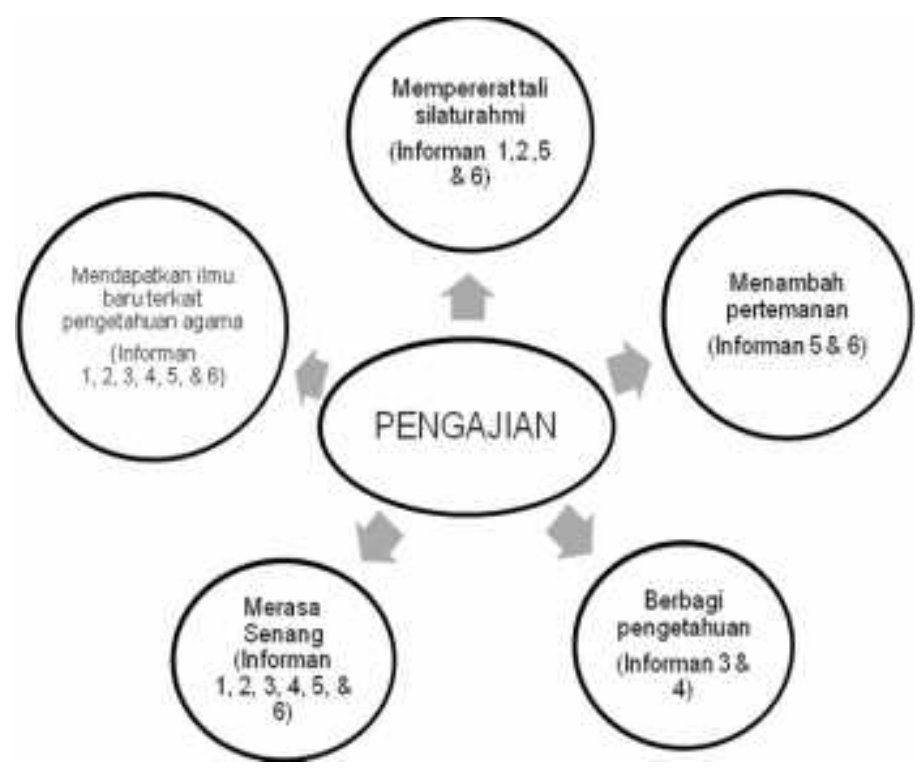

Berdasarkan manfaat yang diperoleh informan selama mengikuti pengajian (seperti: mendapatkan ilmu baru terkait pengetahuan agama; mempererat tali silahturami; menambah pertemanan; berbagi pengetahuan; serta merasa senang) dapat diklasifikasikan menjadi tiga kelompok, yaitu: manfaat spiritual, manfaat sosial, dan manfaat psikologi.

Penelitian-penelitian sebelumnya telah membuktikan bahwa aktivitas keagamaan memberikan kontribusi terhadap kebahagiaan individu (Adam, 2014; Maselko \& Kubzansky, 2006; Sarpitaningtyas, 2012). Secara khusus, Handayani (2011) pernah meneliti tentang pengaruh kegiatan pengajian terhadap aspek psikoreligius pada remaja dengan menggunakan pendekatan kuantitatif. Psikoreligius yang dimaksud dalam penelitian tersebut adalah psikis manusia dalam hubungannya dengan manifestasi 
keagamaan, terutama yang terkait dengan kesadaran agama (religious consciousness) dan pengalaman agama (religious experience). Penelitian Handayani tersebut tidak secara spesifik membahas lansia, berbeda dengan penelitian ini yang secara lebih khusus melibatkan lansia. Selain itu, salah satu hasil penelitian ini lebih terkait dengan religious knowledge daripada aspek psikoreligius yang digunakan dalam penelitian Handayani (2011). Menurut Menouar and Stiftung (2014) religious knowledge berkaitan dengan pemahaman seseorang mengenai konten atau isi dari ajaran-ajaran Allah seperti Al-Qur'an dan As-Sunnah, kehidupan Rasul Allah yaitu Nabi Muhammad, serta pemahaman apa itu Islam secara umum. Meskipun demikian, peneliti memilih menggunakan istilah manfaat spiritual untuk memfasilitasi salah satu tema penelitian yang didapatkan berupa "mendapatkan ilmu baru terkait pengetahuan agama" Peneliti mengunakan istilah ini karena pertimbangan definisi spiritual menurut KBBI (2016) adalah "hal yang berhubungan dengan atau bersifat kejiwaan (rohani, batin)". Informan dalam penelitian ini mengaku mendapatkan siraman rohani melalui kegiatan pengajian. Siraman rohani itu terkait pengetahuan agama yang belum pernah mereka pahami sebelumnya sehingga mereka memiliki tuntunan hidup untuk bagaimana beribadah dan berperilaku secara tepat menurut ajaran agama mereka.

Berikutnya, tema penelitian seperti: "mempererat tali silahturami"; "menambah pertemanan"; dan "berbagi pengetahuan" dikelompokkan kedalam manfaat sosial. Sebagian besar informan memperoleh manfaat sosial dari kegiatan pengajian yang diikuti. Informan menyatakan bahwa pengajian merupakan sarana atau tempat berkumpul dan bersilaturahmi dengan teman lama, menjalin pertemanan baru, serta berbagi pengetahuan dengan orang lain. Penelitian sebelumnya yang dilakukan oleh Musfirotun (2013) menunjukkan bahwa terdapat hubungan positif antara keaktifan mengikuti pengajian malam Jum'at dengan sikap sosial ibu rumah tangga di daerah Salatiga. Pengertian sikap sosial yang dimaksud adalah hubungan dan saling kebergantungan antara manusia dengan manusia yang lain dalam kehidupan bermasyarakat.

Berdasarkan data penelitian, informan menyatakan bahwa mengikuti pengajian mampu menimbulkan perasaan senang. Hal ini dikuatkan dengan hasil penelitian yang dilakukan Putri (2013) menyatakan bahwa terdapat hubungan positif yang sangat signifikan antara religiusitas dengan kesejahteraan psikologis pada lansia muslim. Lansia muslim yang mengikuti pengajian rutin memiliki kesejahteraan psikologis yang lebih tinggi dibandingkan dengan lansia yang tidak mengikuti pengajian. Kesejahteraan psikologis, salah satunya meliputi perasaan senang. Menurut Azani (2012) psychological wellbeing (kesejahteran psikologis) adalah kondisi individu yang ditandai dengan adanya perasaan bahagia, mempunyai kepuasan hidup dan tidak ada gejala-gejala depresi.

Penelitian ini juga menekankan pada sebagian informan, manfaat spiritual atau sosial mampu memunculkan manfaat psikologi seperti perasaan senang atau puas pada informan. Misalnya, tiga informan mengaku mereka merasa senang karena memperoleh ilmu pengetahuan agama yang sebelumnya mereka belum ketahui sehingga dapat disimpulkan bahwa informan tersebut memperoleh manfaat psikologis dari manfaat spiritual. Hal tersebut juga 
didukung oleh pendapat Al Ghazali (dalam Jaapar \& Azahari, 2011) menyatakan bahwa ilmu mengenal Allah SWT (ma'rifat Allah) adalah kunci kebahagiaan. Selanjutnya, sebagian informan juga menyatakan bahwa dengan mempererat hubungan pertemanan, memiliki teman baru, dan berbagi pengetahuan dengan orang lain dapat membuat mereka merasa senang. Hal tersebut mengindikasikan bahwa manfaat sosial dapat membawa ke manfaat psikologis.

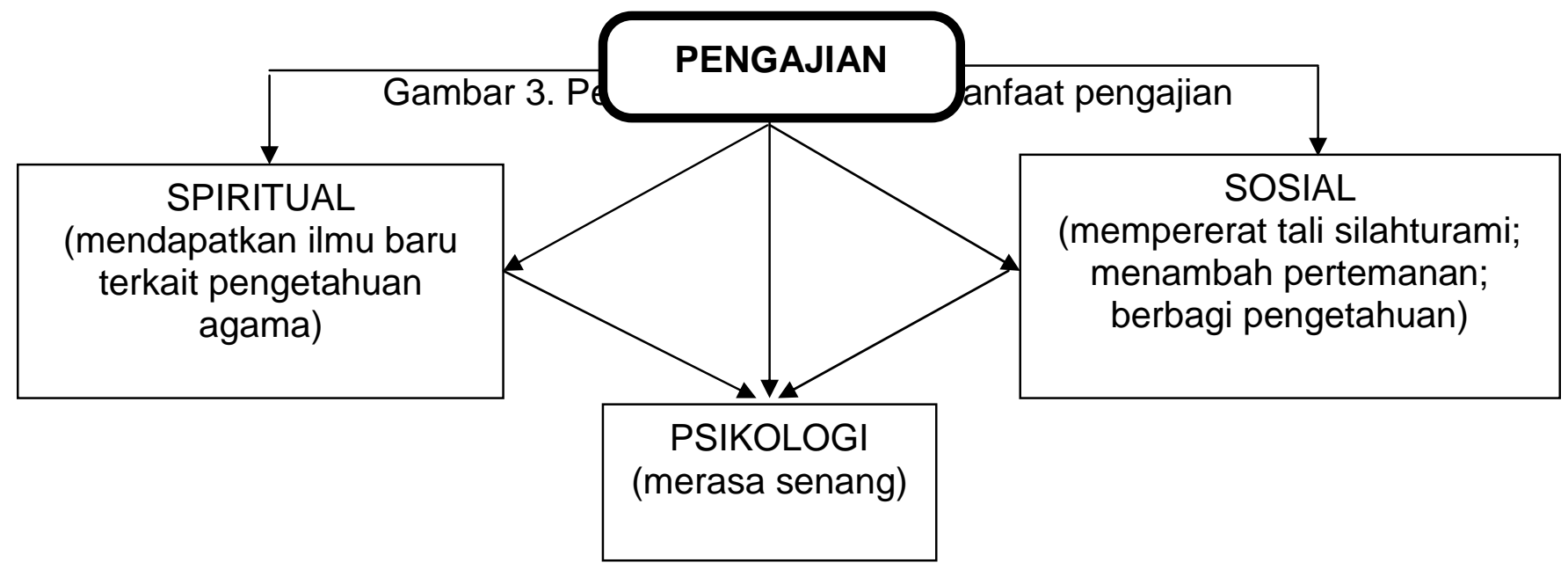

\section{SIMPULAN}

Aktivitas yang dilakukan lansia selama mengikuti kelompok pengajian yang variatif, meliputi: mendengarkan ceramah agama; bertadarus; kajian As-Sunnah; belajar tajwid; kajian tafsir; mengundang dan menyantuni anak yatim; dan membaca doa-doa. Manfaat yang diperoleh dari keikutsertaan lansia dalam pengajian adalah manfaat spiritual (mendapatkan ilmu baru terkait pengetahuan agama), manfaat sosial (mempererat tali silahturami, menambah pertemanan, dan berbagi pengetahuan), serta manfaat psikologis (perasaan senang). Penelitian ini juga menekankan bahwa, pada beberapa informan, manfaat spiritual dan sosial juga dapat membawa manfaat psikologis.

\section{DAFTAR PUSTAKA}

Adams, C. (2014, Desember 25). Religious People Much Happier and Have More Life Satisfication than Others. Daily Mail. Diunduh dari http://dailymail.co.uk.

Alfisyah. (2009). Pengajian dan transformasi sosiokultural dalam masyarakat muslim tradisionalis Banjar. Jurnal Dakwah dan Komunikasi,3(1), 75-89.

Azani. (2012).Gambaran psychological well-being mantan narapidana . Empathy, $1(1), 1-18$

Badan Pusat Statistik [BPS]. (2013). Proyeksi penduduk Indonesia 2010-2035. Jakarta: Badan Pusat Statistik.

Bryner, J. (2010) Desember 16). Does Old Age Bring Happiness or Despair?. Live Science. Diunduh dari http://livescience.com. 
Candra, A. (2012, April 9). Kesehatan jiwa lansia. Kompas. Diunduh dari http://kompas.com

Fauzi, A. (2012). Pengaruh Partisipasi Kegiatan Keagamaan Islam Terhadap Kedisiplinan Siswa yang Beragama Islam Kelas XI Sekolah Menengah Atas Negeri (SMAN) 2 Salatiga Tahun Pelajaran 2011/2012 (Skripsi; Jurusan Tarbiyah Fakultas Pendidikan Agama Islam, Sekolah Tinggi Agama Islam Negeri (STAIN) Salatiga, Salatiga). Diunduh dari http://perpus.iainsalatiga.ac.id/docfiles/fulltext/.

Francis, L. J., Yablon, Y. B., \& Robbins, M.(2014). Religion and happiness: A study amongfemale undergraduate students in Israel. International Journal of International Journal of Jewish Education Research (IJJER), 7, 77-92.

Hakim, N. (2003). Lanjut Usia dan Kecerdasan Ruhani: Menuju Individu yang Khusnul Khotimah. Solo: Buku Kenangan Assosiasi Psikologi Islam (API).

Handayani, W. (2011). Pengaruh Aktivitas Pengajian terhadap Aspek-Aspek Psikoreligius Remaja di Dusun Jambukulon Desa Manggis Mojosongo Kabupaten Boyolali (Skripsi tidak dipublikasikan). Jurusan Tarbiyah Program Studi Agama Islam Sekolah Tinggi Agama Islam Negeri (STAIN) Salatiga, Salatiga.

Jaapar, N. Z., \& Azahari, R. (2011). Model keluarga bahagia menurut Islam. Journal of Fiqh, 8. 25-44.

Kamus Besar Bahasa Indonesia. (2016). Kamus Besar Bahasa Indonesia Online. Diunduh dari http://kbbi.web.id.

Kementrian Kesehatan RI. (2012, Desember). Penyakit tidak menular. Buletin Jendela Data Informasi Kesehatan. Jakarta: Kementrian Kesehatan RI

Laksmana, G. (2013) Oktober 8). Tetap Sehat di Usia Lanjut. Suara Merdeka. Diunduh dari http://suaramerdeka.com.

Maisyaroh, N. (2009). Pengaruh Keaktifan Mengikuti Kegiatan Keagamaan terhadap Pengalaman Keagamaan Siswa Kelas VIII MTsN Bantul Kota Tahun Pelajaran 2008/2009 (Skripsi tidak dipublikasikan). Fakultas Tarbiyah, Universitas Islam Negeri (UIN) Sunan Kalijaga, Yogyakarta. Diunduh dari http://digilib.uinsuka.ac.id/3835/.

Maselko, J., \& Kubzansky, L. D. (2006). Gender Differences in religious practices, spiritual experiences and health: result from the US general social survey. Social Science \& Medicine, 62(11), 2848-2860

Menouar, E. Y. \& Stiftung, B. (2014). The Five Dimensions of Muslim Religiosity : Results of an Empirical Study. Methods, Data, Analyses Journal, 8 (1), 53-78. doi: 10.12758/mda.2014.003.

Musfirotun. (2013). Hubungan Keaktifan Mengikuti Kegiatan Pengajian Malam dengan Sikap Sosial Ibu Rumah Tangga di Karangrejo Rt 003 Rw 003 
Kelurahan Kecandran Kecamatan Sidomukti Kota Salatiga (Skripsi tidak dipublikasikan). Jurusan Tarbiyah Program Studi Agama Islam Sekolah Tinggi Agama Islam Negeri Salatiga, Salatiga.

Putri, L. S. (2013). Hubungan antara Religiusitas dengan Kesejahteraan Psikologis Lansia Muslim (skripsi tidak dipublikasikan). Fakultas Psikologi Universitas Muhammadiyah Surakarta, Surakarta.

QSR International. (2016). NVivo qualitative data analysis software: Version 11. QSR InternationalPty Ltd.

Rafikasari, D. (2015) Juni 7). Mudah Depresi, Libatkan Lansia dalam Kegiatan Sosial. Sindo News. Diunduh dari http://sindonews.com.

Santrock, J. W. (2004). Life-Span Development (Perkembangan Masa Hidup). Jakarta: PT. Gelora Aksara Pratama.

Sarpitaningtyas, M. A. (2012). Motivasi Lansia Melakukan Aktivitas Keagamaan dalam Mengisi Hari Tua di Dusun Dukuh Desa Mandisari Kec. Parakan Kab. Temanggung Tahun 2012 (Skripsi; Fakultas Tarbiyah, Sekolah Tinggi Agama Islam Negeri (STAIN) Salatiga, Salatiga). Diunduh dari perpus.iainsalatiga.ac.id/docfiles/fulltext/bf108d199092e2a6.

Shoim, A., \& Mudzakkir, M. (2013). Makna pengajian wisata rohani di masjid al-falah Tuban. Paradigma, 1(3). Universitas Negeri Surabaya, Surabaya.

Suardiman, S. P. (2011). Psikologi Usia Lanjut. Yogyakarta: Gajah Mada University Press.

Suhartini, R. (2014). Faktor-Faktor Yang Mempengaruhi Kemandirian Orang Lanjut Usia (Studi Kasus di Kelurahan Jambangan) (Thesis; Program Pasca Sarjana, Universitas Airlangga, Surabaya). Diunduh dari http://repository.unand.ac.id/16884/1/.

Sulandari, S. (2014). Older Indonesians' Perceptions of The Facilitators of And Barriers to Optimising Their Physical Activity and Social Engagement (Thesis Program Magister tidak dipublikasikan). Australian Institute for Primary care and Ageing La Trobe University, Australia. 